\title{
APLIKASI SYSTEM REPOSITORY GREEN ACEH UNTUK MENENTUKAN RAMUAN OBAT TRADISIONAL PADA PENYAKIT INFEKSI
}

\author{
Chaeroen Niesa $^{1)}$, Zakial Viki $^{2)}$ \\ ${ }^{12)}$ Dosen Fakultas Komputer dan Multimedia Universitas Islam Kebangsaan Indonesia \\ Bireuen \\ e-mail: jeumalaniesa@gmail.com
}

\begin{abstract}
[Green Aceh Repository System Application to Determine Traditional Medicines for Infectious Diseases] The Aceh Green Repository System is an information system for determining types of plants into traditional medicinal ingredients in Aceh for the treatment of infectious diseases or known as communicable diseases or transmissible diseases, which are clinically real diseases that have signs or medical symptoms and characteristics of the disease. The system determines the type of plant for the treatment of the infectious disease (infectious disease). The system provides questions in the form of symptoms that must be answered by the patient, from the results of this process the system will provide information on what diseases the patient is experiencing in order to get whatever plants are suitable for alternative ingredients in Aceh, Repository Green Aceh is very useful for disseminating information about medicinal plants in Aceh province The development of this repository system is aimed at the success of the industrial era 4.0 and digitizing medicinal plants in Aceh. With this green Aceh repository system, people can get information about plants that can be used as drugs for diseases to be cured.
\end{abstract}

Keywords: Framework, Repository, Algoritma, Green Aceh

\begin{abstract}
Abstrak
Sistem Repository Green Aceh merupakan sistem informasi untuk menentukan jenis tumbuhan menjadi ramuan obat tradisional yang ada di aceh untuk pengobatan penyakit infeksi atau dikenal sebagai communicable disease atau transmissible disease yaitu penyakit yang nyata secara klinik mempunyai tandatanda atau gejala-gejala medis serta karakteristik penyakitnya. Sistem menentukan jenis tumbuhan untuk pengobatan penyakit infeksi (infectious disease) tersebut. Sistem memberikan pertanyaan berupa gejalagejala yang harus dijawab oleh penderita, dari hasil proses tersebut sistem akan memberikan informasi penyakit apa yang dialami penderita guna mendapatkan tumbuhan apasaja yang sesuai untuk dijadikan ramuan alternative yang ada di aceh, Repository Green Aceh sangat bermanfaat untuk menyebar luaskan informasi tentang tumbuhan obat yang ada di provinsi aceh Pengembangan sistem repository ini tujuan untuk menyukseskan era industri 4.0 dan digitalisasi tumbuhan obat di aceh. Dengan sistem repository green aceh ini masyarakat bisa mendapatkan informasi mengenai tumbuhan yang bisa menjadi obat terhadap penyakit yang akan disembuhkan.
\end{abstract}

Kata Kunci: Framework, Repository, Algorithm, Green Aceh.

\section{Pendahuluan}

Dengan sistem repository green aceh dapat memberikan solusi dalam menentukan penyakit dan cara pengobatan tradisional yang tepat melalui proses diagnosa dengan sistem sehingga informasi akan sangat mudah diperoleh bagi penderita penyakit infeksi terutama informasi jenis ramuan tradisional tumbuhan green Green aceh yang tumbuh di wilayah aceh, pengobatan penyakit secara secara tradisional banyak dilakukan oleh masyarakat Indonesia dalam berbagai penyakit mengingat bahan baku yang diperlukan sangat melimpah mulai dari tanaman pekarangan (Haryanti \& Widiyastuti, 2017; Kodir, Moektiwardoyo, \& Iskandar, 2017; 
Setiawan, 2018), perkebunan maupun dalam hutan belantara sehingga pemilihan pengobatan tradisioanal merupakan alternative pengobatan yang sangat aman tanpa efek samping dan murah (Fuadi, 2019; Yathurramadhan \& Yanti, 2020). Umumnya permasalahan yang didapatkan oleh masyarakat dalam pengobatan tradisional adalah minimnya pengetahuan mengenai green aceh atau tumbuhan obat yang ada diaceh dalam menentukan ramuan-ramuan pengobatan dalam berbagai penyakit (Fitri, Gusti, Dasril, \& Putra, 2019; Husni \& Cahayu, 2019), tidak jarang bahan tersebut terdapat dalam pekarangan rumah serta tidak memerlukan biaya khusus dalam meraciknya. Minimnya pengetahuan mengenai bahan-bahan baku pengobatan tradisional dan cara meraciknya membuat banyak orang sukar dalam membuat ramuan tradisional (Samsinar, Majid, \& Rasma, 2018). Oleh karena itu sangat diperlukan adanya sebuah sistem yang dapat mendiagnosa jenis penyakit infeksi yang diderita oleh penderita supaya dapat memberikan pengobatan dalam bentuk ramuan tradisional melalui sistem repository green aceh sehingga akan menambah pengetahuan masyarakat dalam menggunakan ramuan tradisional (Eldawaty, Asnaldi, Wahyuri, \& Kibadra, 2020; Hasan, 2020; Syahrani \& Asrina, 2020).

Pengertian Sistem Pakar Sistem pakar merupakan cabang dari Artificial Intelligence (AI) yang cukup tua karena sistem ini mulai dikembangkan pada pertengahan tahun 1960. Sistem pakar yang muncul pertama kali adalah Generalpurpose Problem Solver (GPS) yang dikembangkan oleh Newel dan Simon (Hung, 2016).

Kepakaran (Expertise) Kepakaran merupakan suatu pengetahuan yang diperoleh dari pelatihan, membaca, dan pengalaman. Kepakaran inilah yang memungkinkan para ahli dapat mengambil keputusan lebih cepat dan lebih baik daripada seseorang yang bukan pakar. Pakar (Expert) adalah seorang yang mempunyai pengetahuan, pengalaman, dan metode khusus, serta mampu menerapkannya untuk memecahkan masalah atau memberi nasehat. Seorang pakar harus mampu menjelaskan dan mempelajari hal-hal yang berkaitan dengan topic permasalahan, jika perlu harus mampu menyusun kembali pengetahuan-pengetahuan

\section{Metode}

Sistem pakar mendiagnosa penyakit infeksi merupakan sebuah sistem layaknya para pakar yang dapat mendiagnosa jenis penyakit infeksi. Dalam mendiagnosa penyakit infeksi digunakan basis pengtahuan dari para pakar-pakar penyakit infeksi. Sistem yang berbasis web maka dapat digunakan oleh masyarakat luas dalam mendiagnosa penyakit. Adapun hasil dari diagnosa penyakit maka sistem akan memberikan informasi jenis penyakit serta jenis ramuan tradisional yang cocok untuk pengobatan penyakit tersebut.

Analisis Kebutuhan Informasi Agar sistem yang dicanangkan berjalan dengans semestinya maka diperlukan informasi yang valid dalam perancangan sistem. Adapun informasi yang dibutuhkan dalam perancangan sistem antara lain :

1. Informasi mengenai jenis-jenis penyakit dan penyebab timbulnya penyakit infeksi.

2. Informasi tentang gejala-gejala penyakit infeksi baik melalui virus, bakteri dan udara.

3. Informasi jenis-jenis ramuan tradisional yang dapat digunakan dalam pengobatan penyakit infeksi.

Perancangan Sistem Tahapan rancangan sistem menguraikan bagaimana alur input, proses dan output dari sistem yang akan dibangun. Perancangan sistem ini dapat digambarkan melalui diagram aliran data maupun konteks diagram yang akan menggambarkan aliran data terhadap sistem yang dirancang. Pada tahap perancangan ini merupakan bagian yang terpenting dalam merancang sebuah sistem. Untuk mencapai hasil/tujuan dari pada sistem yang akan dibangun maka diperlukan adanya pemodelan sistem kerja dan desain antar muka sedemikian mungkin sehingga akan menghasilkan sebuah aplikasi sesuai dengan yang direncanakan yang meliputi perancangan sistem yaitu konteks diagram, perancangan database dan tabel, rancangan input dan output.

Konteks Diagram (Diagram Context) Untuk menggambarkan pemodelan sistem maka digunakan Diagram konteks yang menggabarkan keseluruhan dari sistem yang akan dirancang. Adapun rancangan konteks diagram dapat dilihat pada gambar berikut : 


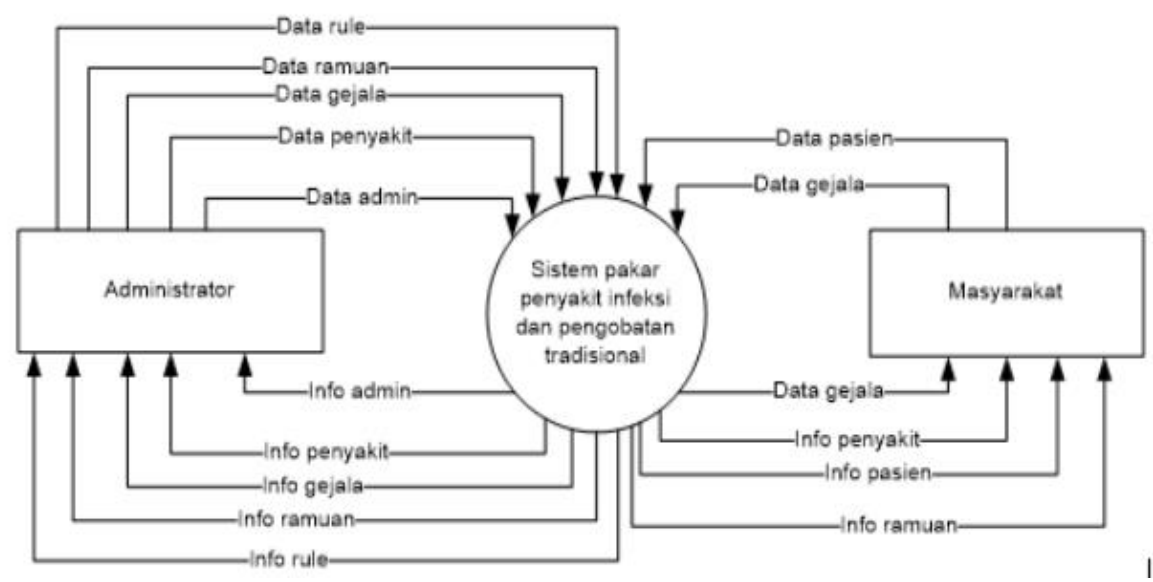

Gambar 1. Konteks Diagram Sistem

\section{Hasil dan Pembahasan}

Pada bagian ini akan dijabarkan hasil penelitian dari repository green Aceh untuk penyakit infeksi dimana akan menghasilkan sebuah sistem berupa sistem informasi repository mengenai ramuan-ramuan tradisional untuk penyakit infeksi, serta sistem dapat melakukan diagnosa terhadap user yang ingin menentukan ramuan tradisional serta mengenali jenis penyakit infeksi yang mungkin menderita pada seseorang. Berikut adalah gambaran hasil repository yang berisikan ramuan-ramuan tradisional.

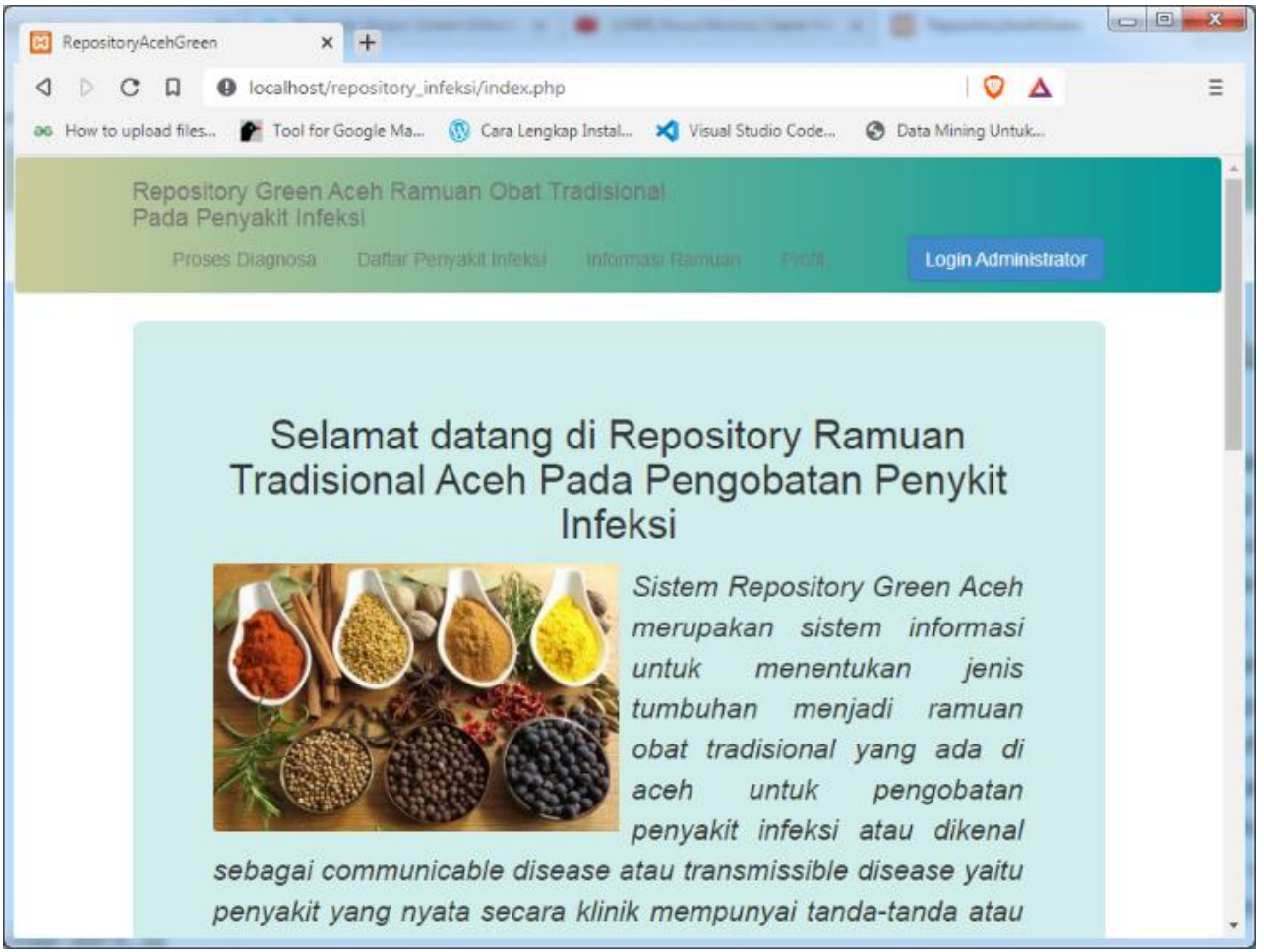

Gambar 2. Tampilan Utama Sistem 


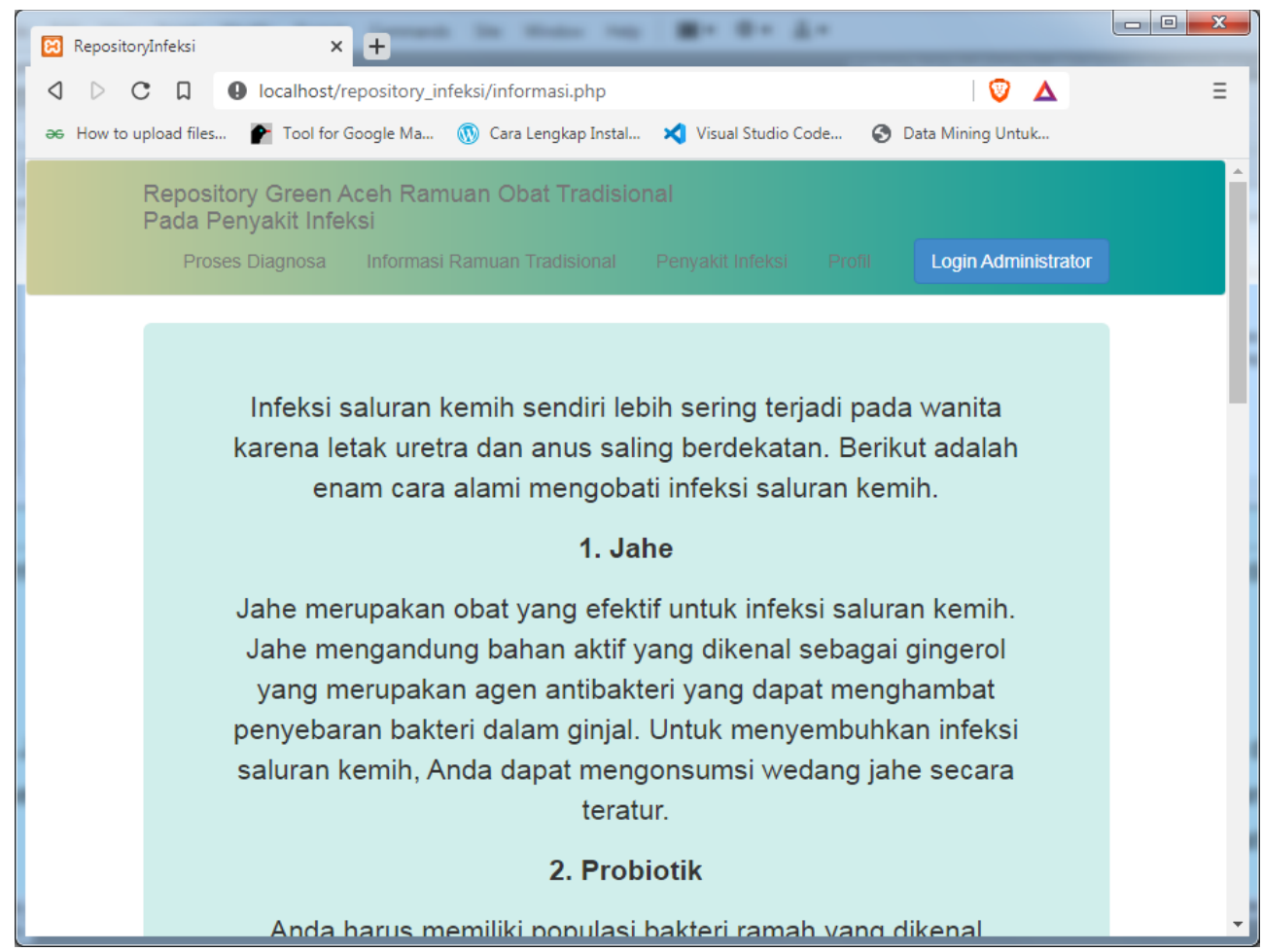

Gambar 3. Repository Ramuan Tradisional

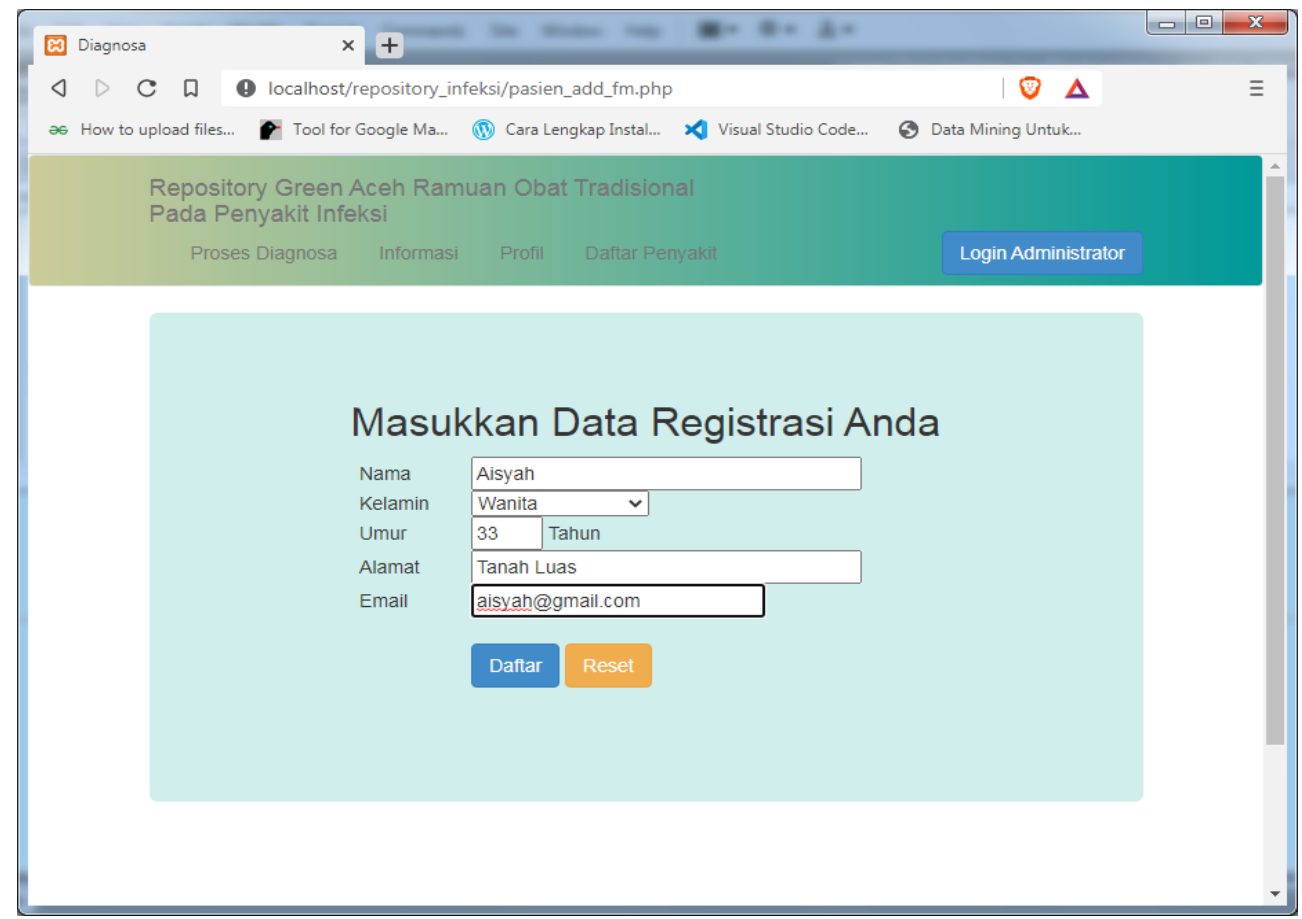

Gambar 4. Registrasi Pengguna 


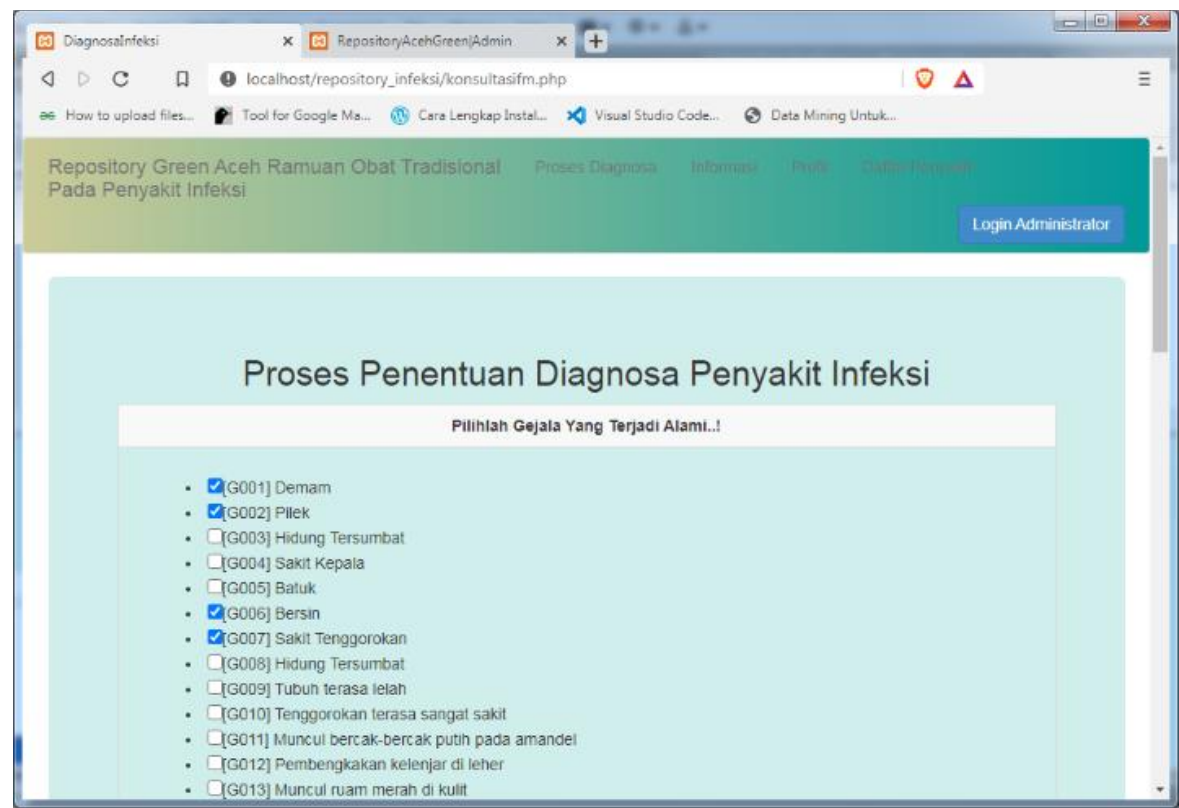

Gambar 5. Diagnosa gejala

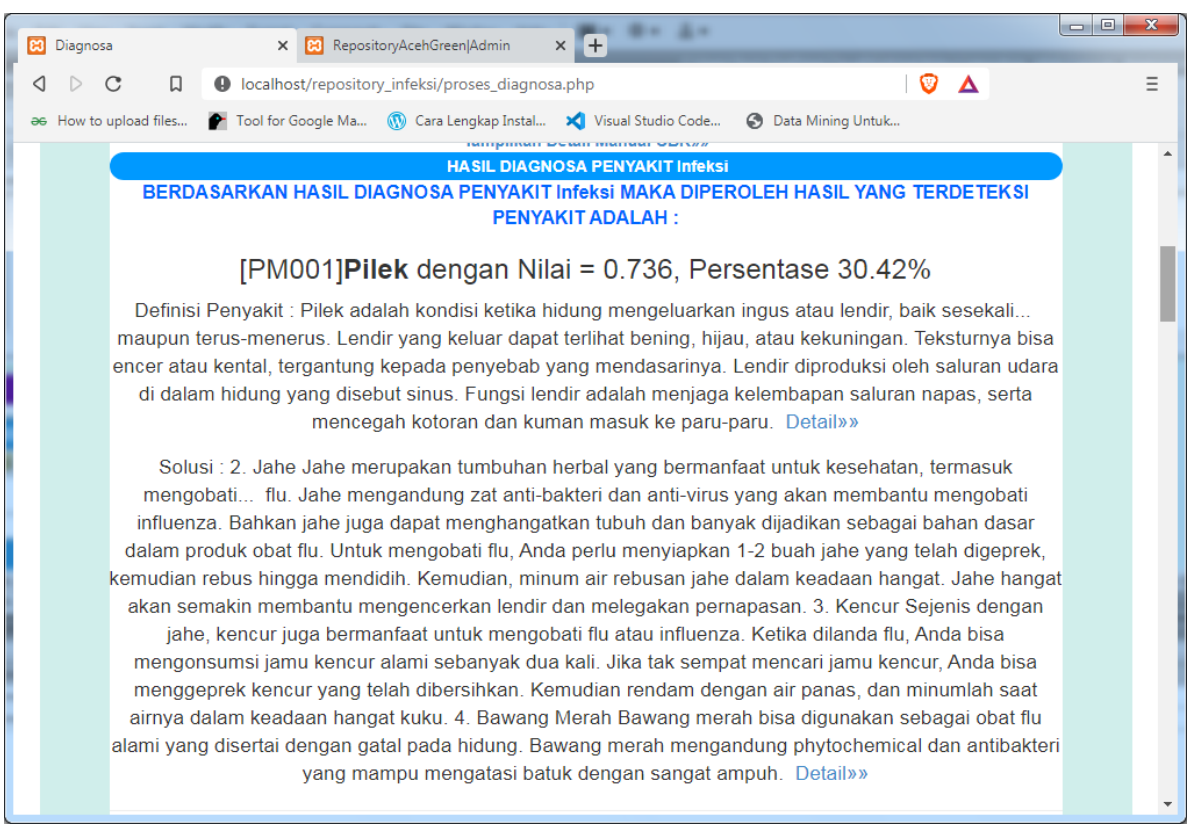

\section{Kesimpulan}

Gambar 6. Proses Diagnosa Penyakit Infeksi

Dari hasil dan pembahasan dapat diambil beberapa kesimpulan, yaitu :

1. Berdasarkan penyedia informasi, bahwa sistem telah bisa menyediakan informasi ramuan tradisional untuk penyakit infeksi.

2. Sistem dapat memberikan dukungan diagnosa kepada user dengan menggunakan fitur sistem pakar, sehingga dapat di analisis ramuan apa yang cocok untuk diberikan kepada pengguna.

3. Agar Sistem dapat disediakan pada perangkat android guna memudahkan update informasi, serta dapat meningkatkan informasi ramuan tradisional berbagai referensi.

\section{Daftar Pustaka}

Eldawaty, E., Asnaldi, A., Wahyuri, A. S., \& Kibadra, K. (2020). Pembuatan Jamu Serbuk Instan Berbasis

Tanaman Obat Keluarga (Toga) Bagi Ibu-Ibu Pkk Di Kelurahan Tarantang Kecamatan Lubuk

Kilangan Kota Padang. Jurnal Berkarya Pengabdian Masyarakat, 2(1), 49-55. 
Fitri, W. E., Gusti, F. R., Dasril, O., \& Putra, A. (2019). Pelatihan dan Pendampingan Budidaya Tanaman Obat Keluarga di Pekarangan Masyarakat Sekitar TPA Air Dingin. Jurnal Abdimas Saintika, 1(1), 145-153.

Fuadi, T. M. (2019). Pengobatan Tradisional Madeung dan Sale pada Ibu Masa Nifas dalam Masyarakat Aceh. Prosiding Biotik, 5(1).

Haryanti, S., \& Widiyastuti, Y. (2017). Aktivitas Sitotoksik pada Sel MCF-7 dari Tumbuhan Indonesia untuk Pengobatan Tradisional Kanker Payudara. Media Penelitian dan Pengembangan Kesehatan, 27(4), 247-254.

Hasan, M. S. (2020). Pemanfaatan Potensi Tanaman Toga Sebagai Obat Herbal untuk Meningkatkan Drajat Hidup Sehat Desa Aka-Akae Kecamatan Watang Sidenreng Kabupaten Sidrap. Paper presented at the Seminar Nasional Pengabdian Kepada Masyarakat.

Hung, W. (2016). All PBL starts here: The problem. Interdisciplinary Journal of problem-based learning, $10(2), 2$.

Husni, E., \& Cahayu, R. J. (2019). PENINGKATAN PENGETAHUAN MASYARAKAT NAGARI MUNGKA KABUPATEN LIMA PULUH KOTA MENGENAI PENGGUNAAN OBAT. BULETIN ILMIAH NAGARI MEMBANGUN, 2(3), 384-390.

Kodir, R. A., Moektiwardoyo, M., \& Iskandar, Y. (2017). Etnofarmasi dan ulasan bioprospektif tumbuhan obat liar dalam pengobatan tradisional kampung adat cikondang, kecamatan pangalengan, kabupaten bandung, jawa barat. Farmaka, 15(1), 26-44.

Samsinar, S., Majid, R., \& Rasma, R. (2018). FAKTOR YANG BERHUBUNGAN DENGAN PERILAKU MASYARAKAT LAMBAKARA TERHADAP PEMANFAATAN PELAYANAN KESEHATAN DI PUSKESMAS LAINEA KABUPATEN KONAWE SELATAN TAHUN 2017. (Jurnal Ilmiah Mahasiswa Kesehatan Masyarakat), 2(8).

Setiawan, I. (2018). Pengobatan Tradisional di Desa Lemahabang Kulon, Kec. Lemahabang, Kab. Cirebon. Patanjala, 10(1), 83-98.

Syahrani, A. R. T., \& Asrina, A. (2020). Pengobatan Tradisional Penyakit Diare Pada Anak Balita di Suku Bajo Kelurahan Bajoe Kecamatan Tanete Riattang Timur Kabupaten Bone. Window of Public Health Journal, 70-78.

Yathurramadhan, H., \& Yanti, S. (2020). Penyuluhan Penggunaan Obat Tradisional di Desa Sigulang. Jurnal Education and Development, 8(1), 4-4. 